\title{
Closed versus Open Innovation: Evolution or Combination?
}

\author{
João P. C. Marques ${ }^{1,2}$ \\ ${ }^{1}$ Polytechnic Institute of Coimbra, ISCAC, Quinta Agrícola-Bencanta, Portugal \\ 2 Department of Economics, Management and Industrial Engineering, Research Unit on Governance, \\ Competitiveness, and Public Policies, University of Aveiro, Portugal \\ Correspondence: João P. C. Marques, ISCAC, Quinta Agrícola-Bencanta 3040-316 Coimbra, Portugal. Tel: \\ 351-239-802-000. E-mail: jmarques@iscac.pt
}

Received: December 23, 2013

Accepted: Feburary 13, $2014 \quad$ Online Published: February 21, 2014

doi:10.5539/ijbm.v9n3p196

URL: http://dx.doi.org/10.5539/ijbm.v9n3p196

\begin{abstract}
The concept of open innovation has attracted great interest from the academic and industrial sectors alike. Despite the ongoing debate, we can see some lack of consistency of its principles. The purpose of this paper is to set out a conceptual reflection on the foundations of innovation and its process and discuss new proposals from the literature on open innovation. We question whether this concept is really a new model, or if it is nothing more than a recent combination, sponsored by academics. We have examined Chesbrough's six principles of open innovation, showing how they are based on a false dichotomy that opposes necessarily closed innovation to open innovation. We show how this new paradigm lacks conceptual clarity confusing innovation with innovation process, resurrecting the linear view, and ignoring many earlier studies. We hope to contribute to the discussion on innovation management and to enrich understanding for all concerned.
\end{abstract}

Keywords: innovation, innovation process, technology transfer, open innovation

\section{Introduction}

The ideas proposed by Chesbrough (2003a; 2003b; 2004) with respect to the concept of open innovation have prompted considerable interest among academics and users. His dichotomous view of innovation, together with a simplistic view of the processes of innovation has helped to spread the concept (Vanhaverbeck, Vrande \& Chesbrough, 2008). However, several issues have been raised recently in the literature (Trott \& Hartmann, 2009, p. 715) that depict this idea as a false question which at most means 'old wine in new bottles'.

Despite these recent developments, the traditional theory of innovation and its concepts and evolutionary perspectives of the innovation process (Rothwell \& Zegveld, 1985; Kline \& Rosenberg, 1986; Cumming, 1988; Lundvall, 1992) show that the topic of open innovation is not yet a finished product.

This article sets out to provide a conceptual reflection of the notion of innovation and its process and to discuss the new proposals raised in the literature in relation to the idea of open innovation. It also questions whether open innovation is really a new model or whether it is a simplistic view, sponsored by academics and researchers. It is hoped that this analysis and appraisal of the concept and process of open innovation will be useful in the discussion on the management of innovation, and that it enriches the understanding of everyone concerned.

The introduction is followed by a section that contains a conceptual review of the key notions on invention and innovation, domains and scopes. Section 3 briefly looks at the main evolutionary milestones in the "process of innovation', from the hundred-year-old linear model to the chain interactions. The discussion on the dichotomy built on the models of closed and open innovation is set out in section 4. Section 5 summarizes certain aspects that seem to be still not resolved by open innovation, and the conclusions offer a final critical view and present some points for further research.

\section{The Concept of Innovation}

Innovation advances through the innovative effort that is developed within society and the economy, with the intervention of all kinds of agents. They may be public or private and include firms, the state, universities and non profit institutions (Caraça, 1993; Lundvall, 1992).

For the purpose of this article, it would seem to be important to distinguish between the concepts of invention 
and innovation. For 'invention' we take the understanding of Caraça (1993, p. 82), thus: 'regardless of its scientific or empirical origin, (...) it consists of an idea or scheme, of foreseeing the possibility of a new product, process or system'. 'Innovation', meanwhile, is taken as 'the first commercialization of a new product, process or system-corresponding to the introduction on the market of the conversion (into a good or service) of such innovation' (Caraça, 1993, p. 82-83). Hence the main difference between them is that 'innovation' is actually the introduction on the market of a new product, process or system, whereas 'invention' is only its discovery and creation.

In practice the notion of innovation is very broad and so various classifications have been developed and used in the literature (Abernathy \& Clark, 1985; Cumming, 1998; Johannessen, Olsen \& Lumpkin, 2001). Most researchers have focused on technology-related innovation such as the introduction of products that need radical changes in the production process. The concept of innovation, however, can be seen as going beyond the radical innovation of technology-based products (Figure 1). It can be regarded as something that brings improvements to products and processes, changes to organizational structures and activities, to exploit new markets. This idea is reflected in the thinking of Lundvall $(1992$, p. 8), who sees innovation as '... on-going processes of learning, searching and exploring, which result in new products, new techniques, new forms of organization and new markets'.

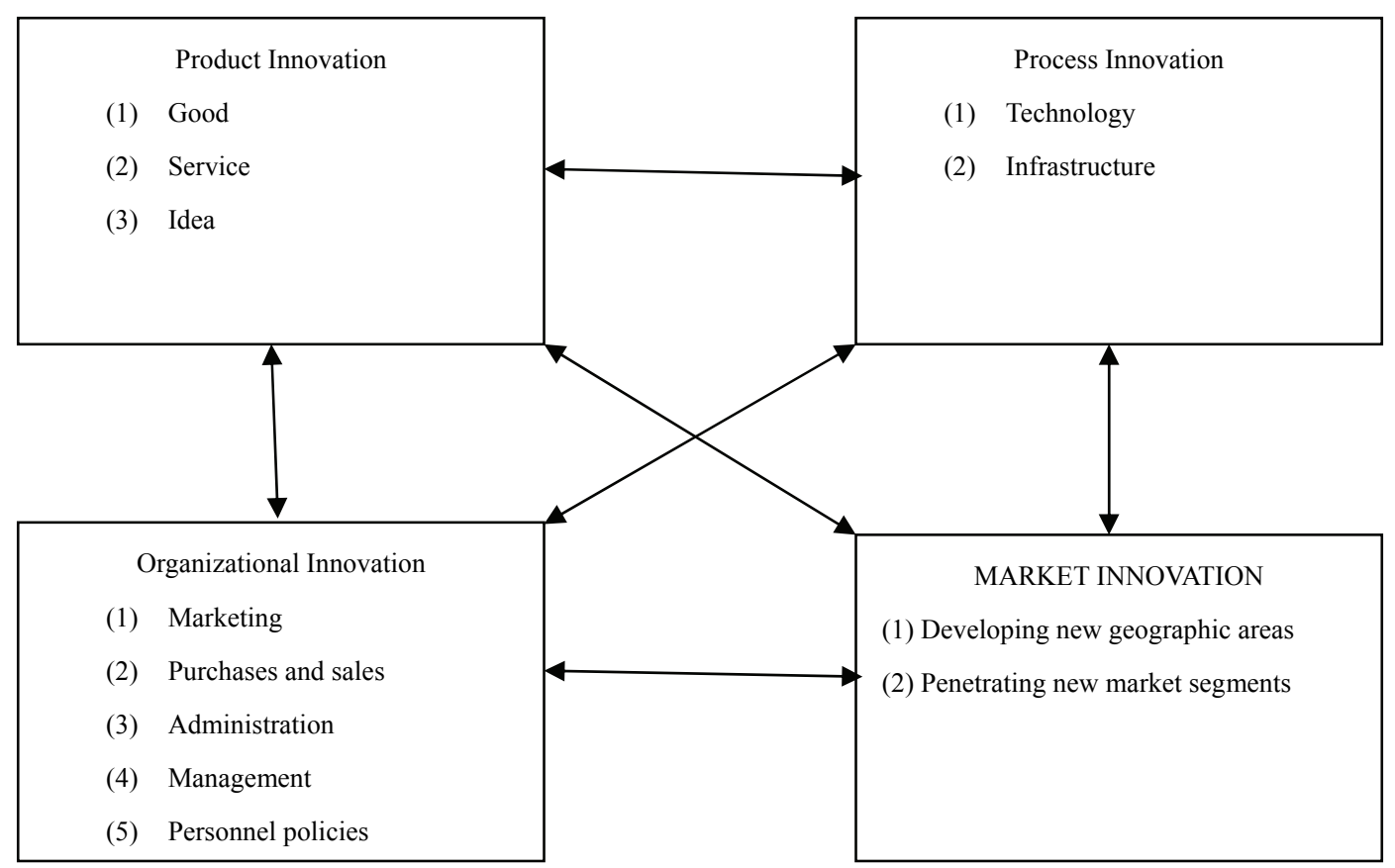

Figure 1. Domains of the concept of innovation

Source: based on Lundvall (1992).

Innovation is often the outcome of changes occurring simultaneously in different areas, where interrelation and interdependence are prominent features (Caraça, Lundvalll \& Mendonça, 2009).

Product innovation can take the form of a good, service or idea that someone sees as being new (Lundvall, 1992; Caraça et al., 2009). One person or organization can thus consider a product as an innovation while another does not (Johannessen et al., 2001). Product innovation can be stimulated by changes in a firm's organizational structure. For example, when the quality of products is improved by a more efficient organization of internal controls. Furthermore, new products can appear when new market segments are explored. For instance, new market segments have been introduced in recent decades by industries in the information and communication technology (ICT) sector, ranging from personal computers to GPS systems (Tidd Bessant \& Pavitt, 1997). Nonetheless, product innovation is essentially associated with change in processes.

Innovation in processes includes adapting existing production lines, installing completely new infrastructure, and implementing new technologies. On the whole, process innovation leads to the creation of new products. 
But process innovation may be necessary to a company's reorganization or to explore new markets (Jenssen \& Aasheim, 2010).

Organizational innovation is about changes in relations of authority, in organizational structure, in job allocation, in remuneration systems, in communication systems and in other aspects of formal interaction between the people in the organization (Slappendel, 1996). Although only a few studies are available on organizational innovation it has nonetheless been gaining importance in all industrial sectors. We can look at the success of standard ISO 9000, for example, which establishes rules for making processes transparent, documenting them, and ensuring they are reproducible and controlled (Tidd et al., 1997).

The last innovation domain concerns market innovation, which involves exploring new territorial markets and penetrating new market segments within the current strategy. As an example, recent developments in the biotechnology sector show that market innovation is strongly interlinked to product and organizational innovation, and less strongly to process innovation (Khilji, Mroczkowski \& Bernstein, 2006).

It is thus clear that the domains and dimensions of innovation are broad, and the notion is multifaceted. While we can distinguish between invention and innovation, because the latter presumes that the new product, process or system is made available to users, the four domains discussed are interwoven as a result of the dynamics of inter- and intra-organizational learning. Innovation is thus 'open' by definition, and its four areas are a reflection of its application in the economy and society as a whole.

\section{The Innovation as a Process}

This was widely studied in the last century. From Schumpeter (1934) until today, many researchers have tackled the topic. Innovation is a key factor in the success of an industrial economy, in competitiveness, in corporate survival, and it is even an essential tool in entrepreneurship (Drucker, 1989).

Kline \& Rosenberg (1986) describe the developmental paths of the innovation process. At first innovation was seen as a linear process instigated within firms, from a series of steps that would start with research, move on to industrial development and continue to production with the innovation eventually being successfully placed on the market. This model is closely linked to the notion of technology-push. It explained innovation particularly well in the first half of the $20^{\text {th }}$ century when there was strong industrial growth in an economy in which demand exceeded supply and so innovations and technical changes were absorbed quite naturally.

The opening of the world economy was conspicuous in the ensuing decades. Changes in ICT, especially the advances in the internet and telecommunications, globalization, competitiveness and the consequent rise in supply to meet demand highlighted the outdated nature of the earlier linear model and brought the interactive paradigm of innovation to the fore, called by Kline \& Rosenberg (1986) the interactive model of the innovation process. This view featured the market-pull perspective, emphasizing the interactivity of the innovation process with the stress on exchange, sharing, interaction and feedback among the actors intervening inside and outside the company, reflecting the opening up of innovation to knowledge bases and the market. Interaction with the science and technology system would dominate the process of resolving technical problems, the search for solutions and progress.

Caraça et al. (2009) recently foresaw new fronts in the opening up of science and R\&D. The first was designated a science and technology system, which had already been formulated. The second was an opening up of the market through knowledge, information and advances in consumer knowledge, new human needs, opportunities and advances, and the third was an opening up to knowledge within a firm, designated organizational opening up to new management and organization methods, new processes and organizational forms. The evolutionary dynamics, the constant change of the macro and micro environment produce effects on outputs in the form of product, process, organization and market innovation.

These evolutionary aspects of the innovation process highlight the importance of knowledge/technology transfer and the notion of absorptive capacity as being crucial to learning, expressed as a multiplicity of interactions in the dynamics driving cooperation, exchange and sharing of knowledge/technology (Rothwell, 1992; Senker \& Faulkner, 1996). The linear view of innovation, which focused on science and had a strong tendency to be "closed", was thus progressively replaced by an "open", interactive view based on the continuous learning of all the actors involved.

\section{Open Innovation View}

Open innovation is an innovation management model as developed by Chesbrough (2003a; 2003b; 2004), which assumes that innovation is based on firms' need to combine their internal and external technological developments to produce a successful innovation that creates added value for the firm. Chesbrough contrasts a 
supposed closed innovation followed by some firms with an open innovation, which would be a desirable achievement.

Chesbrough (2003a; 2003b) thus presents six principles of innovation, so-called 'closed innovation', countering them with the principles of so-called "open innovation" (Figure 2).

\begin{tabular}{|c|c|}
\hline Closed innovation & Open innovation \\
\hline $1-$ All the smart people work in our organization. & 1 - Not all the smart people work in our organization. \\
\hline $\begin{array}{l}2-\text { To profit from R\&D we have to discover, } \\
\text { develop and supply everything ourselves. }\end{array}$ & $\begin{array}{l}2 \text { - External } R \& D \text { can create value for our organization. } \\
3 \text { - Internal } R \& D \text { is needed to grasp that value. }\end{array}$ \\
\hline $\begin{array}{l}3 \text { - Only if we discover it will we manage to get it } \\
\text { to market first. }\end{array}$ & $\begin{array}{l}4-\text { We have to be involved in basic research to benefit } \\
\text { from it, but the discovery does not have to be ours. }\end{array}$ \\
\hline $\begin{array}{l}4 \text { - If our organization is the first to commercialize } \\
\text { an innovation, we will beat our rivals. }\end{array}$ & $\begin{array}{l}5 \text { - If we make better use of external and internal ideas } \\
\text { and unify the knowledge created, we will win. }\end{array}$ \\
\hline $\begin{array}{l}5 \text { - If we create the most and best ideas in our } \\
\text { industry, we will win. }\end{array}$ & $\begin{array}{l}6 \text { - We should optimize the results of our organization, } \\
\text { combining the sale or licensing of our innovation with }\end{array}$ \\
\hline $\begin{array}{l}6 \text { - If we have full control over the innovation } \\
\text { process our rivals will not be able to profit from } \\
\text { our innovative ideas. }\end{array}$ & $\begin{array}{l}\text { the purchase of external innovation processes whenever } \\
\text { they are more efficient and economic. }\end{array}$ \\
\hline
\end{tabular}

Figure 2. Principles of closed innovation and open innovation

Source: based on Chesbrough (2003a; 2003b).

According to the innovation definition and broad interpretation of innovation process mentioned in sections 2 and 3 , the presentation and contrasting of these six principles seems to reduce the reality in a simplistic and facile manner. For example, the first principle of the closed innovation model holds that all knowledge that provided the basis for the development of R\&D was produced internally by an organization. However, Allen \& Cowen (1969) had already identified the role of the 'doorkeeper' in organizations, which was to connect the internal scientists and groups scientists outside the company. This concept was later reinforced by Tushman (1977). Furthermore, the literature on innovation for many years stressed social interaction, which affords the opportunity to exchange thoughts, ideas and opinions (Rothwell \& Zegveld, 1985; Rothwell, 1991; Cohen \& Leventhal, 1989). All these studies seem to have been ignored in favour of the first principle of open innovation.

The second principle of closed innovation can be contrasted with the arguments that in the 1970s and 80s technological partnerships increased at a very rapid rate. With the cost of R\&D increasing all the time, no firm could be competitive if it remained in technological isolation. So the forging of strategic alliances would often have been the solution adopted so that companies could flourish. So cooperation and partnership between companies does not seem to be anything new, since they have been part of corporate practice for a long time (Grow \& Nath, 1990; Rothwell, 1991; Tidd et al., 1997). In addition, the concept of open innovation appears to disregard research on technology transfer and absorptive capacity (Dosi, 1982; Freeman, 1987), with particular reference to the need to join forces, not only with respect to access to technology but in terms of R\&D, too, so that companies can benefit from technology developed outside the organization.

Balancing the third principle of closed innovation, Trott \& Hartman (2009) mention two companies as examples, Corning and Xerox. Corning is noted as having chosen to make strategic alliances based on technology, while Xerox, despite having cutting-edge technology, did not do so. Recent changes made by companies in relation to the management of technological resources and $R \& D$ are mentioned and they also specify the 3 important factors identified by Rothwell \& Zegveld (1985), which are: the technology explosion; the shortening of the technology cycle, and the globalization of technology. The importance of technology-based companies acquiring technology indicates a shift from the internal focus on R\&D by transferring it to the outside, bearing in mind that the technology base of a company is an asset that represents its real capacity in terms of human, technological and financial resources (Rothwell, 1991). The economic potential of the benefits of owning intellectual and industrial property is ignored, too, and of capitalizing intangible assets (Bainbridge, 1996).

The fourth principle does not seem to be a linear idea since examples are known of pioneering firms that have been overtaken by followers. For instance, the internet browser, Mosaic (1993) was leapfrogged by Internet 
Explorer, and the 1994 search engine Altavista was overtaken by Google in 2000 (Trott \& Hartman, 2009). The key point is that the firms recognize that success in innovation involves a great deal more than simply being the first to get a product to market. It is worth noting that according to Freeman (1982) the 4 innovation strategies adopted by technology-intensive firms are aggressive leadership, fastest follower (defensive), cost minimization (imitation) and specialization in traditional segments. These describe the strategic postures possible for many firms with respect to technological innovation, including external acquisition and licensing (Granstrand, Bohlin, Oskarsson, \& Sjoberg, 1992), demonstrating the huge financial benefits underlying the ownership of intellectual property (Bainbridge, 1996).

The fifth principle takes us back to the old idea of the more R\&D the better. This is only actually true if the outcome of the R\&D is subsequently applied to develop new products. Furthermore, the technology should always be developed with the competitive market in which the company operates kept firmly in mind. R\&D is just one possible input that firms have for innovating, not the only one (Hoffman, Parejo, Bessant \& Perren, 1998). At the moment $R \& D$ needs are managed in a manner that is fully integrated in the strategic management of the business (Dussauge \& Ramanantsoa, 1987; Grow \& Nath, 1990; Barney, 2001).

The 6th principle was described by Trott \& Hartman (2009) as an irrational principle because, for example, the sale of patents or firms buying and selling each others' licences has been an acceptable way of doing business. This mutual interest in having licensing agreements between companies is a common denominator for them and could entail excellent results for their business (Tidd et al., 1997).

The attempt to reduce the evolution of the concept of innovation and its process to a dichotomous paradigm between "open innovation" versus "closed innovation" seems to be a vision that is both exaggerated and false, equally in theory and in practice. At the theoretical level because it confuses the concept of "innovation presented in section 2' with that of 'innovation process' discussed in section 3, meaning a conceptual regression to the 'technology-push' paradigm. At the practical level, because it reduces the fact of innovation to the technological and industrial scope, disregarding the other innovation domains mentioned by Lundvall (1992) discussed in section 2, and also because it forgets the specific difficulties of the small and micro businesses in developing R\&D and in gaining access to external knowledge networks (Rothwell, 1991; Tsai, 2005).

In addition, the diffusion of this dichotomy appears to be merely a psychological tactic that is useful and stimulating to get open innovation to firms. For this dichotomy to be genuine, it could be suggested that some managers may have adopted innovation strategies as a matter of 'fashion', offering little by way of criticism with respect to the original concepts of the sundry domains of innovation and their contextualization and focusing on marginal factors.

\section{Problems not Resolved by Open Innovation}

Despite the success of open innovation in the academic environment, in the sale of books and in the number of companies that took it up, this innovation model is not held to be perfect. It seems to be a linear model par excellence, consisting basically of a variation of the 'stage-gate' model (Cooper \& Kleinschmidt, 1986), characterized by a funnel with holes that would let ideas be exchanged throughout the process, while the flow takes a forward linear course. This linearity is indicated as a conceptual failing (Trott \& Hartman, 2009), with the solution involving the integration of the principles of the interactive model of innovation and learning proposed by Caraça et al. (2009), which states that innovation originates in a cyclical process of feedback from learning, where there are neither fixed points of origin nor of obsolescence, and therefore distancing themselves from the technology-push and market-pull models.

Another problem is the flight of knowledge. Open innovation view favours the sharing of information, but this openness can lead to the flight of sensitive knowledge, both commercial and technological. The challenge proposed is how to strike a balance between an exchange of knowledge that is enough to develop R\&D and yet remain in control of these flows (Trott \& Hartman, 2009).

The third problem is related to the opening up to the flows of knowledge and learning with respect to the global economy, which led firms like Procter \& Gamble, and Philips to establish internal frontiers with limits on the free flow of information between their departments (Hacievliyagil, Auger, Maisonneuve \& Hartmann, 2008; Meer, 2007). If this is confirmed, then obviously there is an incompatibility that the model does not explain.

The final problem concerns the strong influence of market and customers needs as sources of innovation in global economy (Caraça et al, 2009). These are critical factors to product, process, organizational and market innovation. Chesbrough view ignores this reality. 


\section{Conclusion}

This article has tried to provide a critical review of open innovation, criticizing the adoption of this concept on the basis that the research lacks the credit to justify the principles that gave rise to it. The model carries on with the linear view of innovation based on 'technology-push', to the detriment of interactive rationales and learning throughout the whole innovation process.

In the first place the lack of conceptual clarity is questioned. The introduction of the open innovation model does not distinguish between the concepts of innovation and the process of innovation; it confuses the introduction and commercialization of an innovation on the market with the process that brought it into existence. As Caraça (1993) says, an innovation is only that if it is open, that is to say, if it ends up by being commercialized. The process of innovation, however, can be closed or open, or semi-closed or semi-open, depending on the strategy of the company. The view of innovation strongly based on R\&D and the absolute need to develop internal capacity to integrate external R\&D is also open to criticism.

The readiness with which the concept has been embraced by companies is questioned, too. This acceptance could perhaps be explained by the simplicity of the new model, the limitations of the supposed 'closed innovation' model and the false myth that this latter one is still followed by a great many firms. It has further been argued that the approach of this dichotomy gives the idea that opting for one of the two models automatically excludes the other, in the belief that if something is wrong then the opposite must surely be right. Such polarization does not allow something to be partly right and wrong at the same time.

Another issue examined is the adherence to the model by many reputable companies, as a matter of business strategy (Hacievliyagil et al., 2008). They publicize the model making its implementation in a laboratory in real life, subject to experiment and obtaining results which could lead to its improvement. Nonetheless, this movement could fade away when the firms see that this is not the remedy to cure all ills and that R\&D is only one of the possible inputs in the process of innovation, but by no means the only one (Hoffman et al., 1998). Faced with these facts, it is advisable to regard open innovation as a field of study still in development, subject to large changes, and it should also be viewed with an open mind.

\subsection{Directions for Further Research}

More important than talking about open and closed innovation in the current context of globalization of market innovation, is helping to understand the learning processes inside and outside companies, how they acquire knowledge, how they organize their resources and capabilities to sustain the business strategy. A careful look at the interactive model of innovation and learning proposed by Caraça et al. (2009), can contribute to a better integration of the multitude of factors that influence the innovation process in the modern global economy.

\section{References}

Abernathy, J., \& Clark, K. (1985). Mapping the winds of change. Research Policy, 3, 3-22. http://dx.doi.org/10.1016/0048-7333(85)90021-6

Allen, T. J., \& Cohen, W. (1969). Information flow in research and development laboratories. Administrative Science Quarterly, 14(1), 12-19. http://dx.doi.org/10.2307/2391357

Bainbridge, D. I. (1996). Intellectual Property. Financial Times (3rd ed.). London: Bitman Publishing.

Barney, J. B. (2001). Is the resource based view a useful perspective for strategic management research? Academy of Management Review, 26(1), 41-56. http://dx.doi.org/10.5465/amr.2001.4011938

Caraça, J. M. G. (1993). Do Saber ao Fazer: Porquê organizar a Ciência? Lisbon: Gradiva.

Caraça, J. M. G., Lundvall, B. A., \& Mendonça, S. (2009). The changing role of science in the innovation process: from Queen to Cinderella? Technological Forecasting and Social Change, 76(6), 861-867. http://dx.doi.org/10.1016/j.techfore.2008.08.003

Chesbrough, H. (2003a). Open Innovation: The new imperative for creating and profiting from technology. Boston, MA: Harvard Business School Press.

Chesbrough, H. (2003b). The era of open innovation. MIT Sloan Management Review, 44(3), 35-41.

Chesbrough, H. (2004). Managing open innovation. Research-Technology Management, 47(1), 23-26.

Cohen, W., \& Levinthal, D. (1989). Innovation and Learning: The two faces of R\&D. The Economic Journal, 99, 569-596. http://dx.doi.org/10.2307/2233763

Cooper, R. G., \& Kleinschmidt, E. J. (1986). An investigation into the new product process: steps and 
deficiencies and impact. Journal of Product Innovation Management, 3, 71-85. http://dx.doi.org/10.1111/1540-5885.320071

Cumming, B. S. (1998). Innovation overview and future challenges. European Journal of Innovation Management, 1(1), 21-9. http://dx.doi.org/10.1108/14601069810368485

Dosi, G. (1982). Technical Paradigms and Technological Trajectories - A suggested interpretation of the determinants and directions of technical change. Research Policy, 11(3), 147-162. http://dx.doi.org/10.1016/0048-7333(82)90016-6

Drucker, P. (1989). Inovação e Gestão (3rd ed.). Lisbon: Presença.

Dussauge, P., \& Ramanantsoa, B. (1987). Technologie et stratégie d'entreprise. Paris: McGraw-Hill.

Freeman, C. (1982). The Economics of Industrial Innovation (2nd ed.). London: Frances Pinter.

Freeman, C. (1987). Technology Policy and Economic Performance: Lessons from Japan. London: Pinter Publishers.

Granstrand, O., Bohlin, C., Oskarsson, C., \& Sjoberg, N. (1992). External technology acquisition in large multi-technology corporations. $R \& D \quad$ Management, $22(2), \quad 111-133$. http://dx.doi.org/10.1111/j.1467-9310.1992.tb00801.x

Grow, M., \& Nath, S. (1990). Technology strategy development in Japanese industry: an assessment of market $\begin{array}{llll}\text { and } \quad \text { government } & \text { 333-346. }\end{array}$ http://dx.doi.org/10.1016/0166-4972(90)90017-e

Hacievliyagil, N. K., Auger, J. F., Maisonneuve, Y., \& Hartmann, A. (2008). The position of virtual knowledge brokers in the core process of open innovation. International Journal of Knowledge, Technology and Society, 3(5), 47-60.

Hoffman, K., Parejo, M., Bessant, J., \& Perren, L. (1998). Small firms, R\&D, technology and innovation in the UK: a literature review. Technovation, 16, 19-35. http://dx.doi.org/10.1016/s0166-4972(97)00102-8

Jenssen, J., \& Aasheim, K. (2010). Organizational innovation promoters and performance effects in small, knowledge-intensive firms. Entrepreneurship and Innovation Management, 11(1), 19-27. http://dx.doi.org/10.5367/000000010790772476

Johannessen, J. A., Olsen, B., \& Lumpkin, G. (2001). Innovation as newness: what is new, how new and new to whom? European Journal of Innovation Management, 4(1), 20-31. http://dx.doi.org/10.1108/14601060110365547

Khilji, S., Mroczkowski, T., \& Bernstein, B. (2006). From Invention to Innovation: Toward Developing an Integrated Innovation Model for Biotech Firms. The Journal of Product Innovation Management, 23, 528-540. http://dx.doi.org/10.1111/j.1540-5885.2006.00222.x

Kline, S. J., \& Rosenberg, N. (1986). An Overview of Innovation. In National Academy of Engineering (Eds.), The Positive Sum Strategy: Harnessing Technology for Economic Growth (pp. 275-305). Washington, DC: The National Academy Press.

Lundvall, B. A. (1992). National Systems of Innovation: Towards a theory of Innovation and Interactive Learning. London: Frances Pinter.

Meer, H. (2007). Open Innovation-The Dutch treat: Challenges in Thinking in Business Models. Creativity and Innovation Management, 16, 192-202. http://dx.doi.org/10.1111/j.1467-8691.2007.00433.x

Rothwell, R., \& Zegveld. (1985). Reindustrialisation and Technology. London: Longman.

Rothwell, R. (1991). External networking and innovation in small and medium-sized manufacturing firms in Europe. Technovation, 11(2), 93-112. http://dx.doi.org/10.1016/0166-4972(91)90040-b

Rothwell, R. (1992). Sucessful industrial innovation: critical factors for the 1990's. R\&D Management, 22(3), 221-239. http://dx.doi.org/10.1111/j.1467-9310.1992.tb00812.x

Schumpeter, J. (1934). The Theory of Economic Development. Cambridge, MA: Harvard Economic Studies.

Senker, J., \& Faulkner, W. (1996). Networks, tacit knowledge and innovation. In Coombs, R., Richards, A., Saviotti, P., Walsh, V., \& Elgar, E. (Eds.), Technological Collaboration: The dynamics of cooperation in Industrial Innovation (pp. 76-97). Cheltenham: Edward Elgar Publishing Ltd.

Slappendel, C. (1996). Perspectives on innovation in organizations. Organization Studies, 17(1), 107-129. 
http://dx.doi.org/10.1177/017084069601700105

Tsai, K. H. (2005). R\&D productivity and firm size: a nonlinear examination. Technovation, 25, 795-803. http://dx.doi.org/10.1016/j.technovation.2003.12.004

Tidd, J., Bessant, J., \& Pavitt, K. (1997). Managing innovation: integration technological, market and organizational change. Manchester: John Wiley and Sons.

Trott, P., \& Hartmann, W. (2009). Why open innovation is old wine in new bottles. International Journal of Innovation Management, 13(4), 715-736. http://dx.doi.org/10.1142/s1363919609002509

Tushman, M. L. (1977). Technical communication in R\&D laboratories: The impact of project work characteristics. Academy of Management Journal, 20, 624-645. http://dx.doi.org/10.2307/255704

Vanhaverbeck, W., Van De Vrande, V., \& Chesbrough, H. (2008). Understanding the Advantages of Open Innovation Practices in Corporate Venturing in Terms of Real Options. Creativity and Innovation Management, 17, 251-258. http://dx.doi.org/10.1111/j.1467-8691.2008.00499.x

\section{Copyrights}

Copyright for this article is retained by the author(s), with first publication rights granted to the journal.

This is an open-access article distributed under the terms and conditions of the Creative Commons Attribution license (http://creativecommons.org/licenses/by/3.0/). 